\title{
EFEKTI KAROTIDNOG STENTINGA NA KOGNITIVNE FUNKCIJE KOD BOLESNIKA SA STENOZOM KAROTIDNE ARTERIJE
}

\author{
Marijana Stošić, Marija Andjelković-Apostolović, Nataša Đinđić, Dušica Ilić, \\ Saša Ristić, Miroslava Živković, Dragan Stojanov
}

(Vol 57, No 3, Oktobar, 2018)

\begin{abstract}
U radu " EFEKTI KAROTIDNOG STENTINGA NA KOGNITIVNE FUNKCIJE KOD BOLESNIKA SA STENOZOM KAROTIDNE ARTERIJE" autora Marijana Stošić, Marija Andjelković-Apostolović, Nataša Đinđić, Dušica Ilić, Saša Ristić, Miroslava Živković, Dragan Stojanov, objavljenom u časopisu AMM za 2018. godinu broj 57 (3) na stranama od 23-32, došlo je do tehničke greške, pri kojoj je odštampan pogrešan sažetak na srpskom za ovaj rad. Ovom prilikom se izvinjavamo autorima i čitaocima. Uz saglasnost autora, u ovom broju objavljujemo ispravan spisak referenci.
\end{abstract}

Acta Medica Medianae 2019;58(1):138-139.

Stenting karotidne arterije (CAS) je značajan terapijski modalitet kod pacijenata sa stenozom karotidne arterije. Stenoza unutrašnje karotidne arterije visokog stepena dovod do poremećaja i deficita kognitivnih funkcija, čak i kod asimptomatskih bolesnika. Potencijalni uticaj stentiranja karotidne arterije na kognitivne funkcije bolesnika sa stenozom karotidne arterije nije dovoljno istražen. Cilj ovog istraživanja bio je da se ispita uticaj karotidnog stentinga na kognitivne funkcije kod bolesnika sa stenozom karotidne arterije visokog stepena, na različite kognitivne domene, kao i na potencijalne faktore koji mogu uticati na kognitivne funkcije kod ovih bolesnika.

U studiju je uključeno 25 bolesnika sa simptomatskom i asimptomatskom stenozom karotidne arterije i 25 zdravih ispitanika. Kognitivne funkcije su evaluirane jedan dan pre procedure i tri meseca nakon procedure. Za evaluaciju kognitivnih funkcija korišćen je Montreal cognitive assessment (MoCA)-test.

Ukupan MoCA skor kod bolesnika pre intervencije bio je značajno niži u odnosu na kontrolnu grupu. Ovaj skor je značajno povišen tri meseca nakon intervencije. Značajano su se popravili rezultati za pažnju, egzekutivne funkcije i pamćenje.

Karotidni stenting može poboljšati ukupne kognitivne funkcije kao i pažnju, egzekutivne funkcije i pamćenje kod simptomatskih i asimptomatskih bolesnika sa stenozom karotidne arterije visokog stepena. Visok nivo holesterola predstavlja nezavisni faktor rizika za deficit kognitivnih funkcije pre revaskularizacije, dok nizak nivo obrazovanja predstavlja nezavistan faktor za nizak nivo kognitivnih funkcija nakon revaskularizacije.

Linked article is avaliable here.

https://publisher.medfak.ni.ac.rs/AMM_1/2018/2018-3-broj/celi_radovi/03Marijana\%20Stosic.pdf 


\title{
EFFECT OF CAROTID ARTERY STENTING ON COGNITIVE FUNCTION IN PATIENTS WITH INTERNAL CAROTID ARTERY STENOSIS
}

\author{
Marijana Stošić, Marija Andjelković-Apostolović, Nataša Djindjić, Dušica Ilić, \\ Saša Ristić, Miroslava Zivković, Dragan Stojanov \\ (Vol 57, No 3, October, 2018) \\ In the paper titled " EFFECT OF CAROTID ARTERY STENTING ON COGNITIVE FUNCTION IN \\ PATIENTS WITH INTERNAL CAROTID ARTERY STENOSIS" by Marijana Stošić, Marija Andjelković- \\ Apostolović, Nataša Djindjić, Dušica Ilić, Saša Ristić, Miroslava Živković, Dragan Stojanov, \\ published in AMM journal in 2018, number 57 (3), there occurred a technical error on the page 32, \\ with published wrong summary on Serbian for the paper. We hereby apologize to the authors and \\ readers. With authors' approval, we are now publishing the correct summary.
}

Acta Medica Medianae 2018;57(3):23-32. 